DOI

\author{
๑ Л. Б. Маркін, Л. М. Ященко
}

Лъвівсъкий національний медичний університет імені Данила Галицького

\title{
ПРОЛОНГОВАНА ТА ПЕРЕНОШЕНА ВАГІТНІСТЬ. КЛІНІКО-МОРФОЛОГІЧНІ АСПЕКТИ
}

ПРОЛОНГОВАНА ТА ПЕРЕНОШЕНА ВАГІТНІСТЬ. КЛІНІКО-МОРФОЛОГІЧНІ АСПЕКТИ. НамИ проведене динамічне спостереження за 15 вагітними з моменту їх госпіталізації до виписки після пологів. Жінки розподілені на 3 групи: перша 5 жінок із пролонгованою вагітністю 41 тиждень; друга група - 5 жінок з переношеною вагітністю 42 тижні; третя група - 5 жінок з фрізіологічним перебігом вагітності. Критерії включення до дослідження: одноплідна вагітність, гестаційний вік >280 днів, відсутність тяжкої екстрагенітальної патології, переношена вагітність в анамнезі. Усі вагітні були обстежені в повному клініко-лабораторному обсязі. У процесі обстеження проводили загальноклінічні (клініко-анамнестичні, лабораторні), спеціальні дослідження: ультразвукове дослідження з доплерометрією, кардіотокографрію, морфологічні дослідження плаценти та амніотичної оболонки. Показано, що в 60 \% жінок із пролонгованою вагітністю в анамнезі спостерігалися перенесені в дитинстві інсрекційні захворювання (краснуха, скарлатина, паротит). Середній вік менархе у жінок із пролонгованою й переношеною вагітністю становив $15 \pm 0,5$ років. У 40 \% вагітних із переношеною вагітністю виявлено анемію легкого ступеня (Нв 98-100 г/л). Під час пологів у 60 \% жінок із переношеною та в $40 \%$ зі пролонгованою вагітністю спостерігалось передчасне вилиття навколоплодових вод. Морфологічні дослідження показали, що дистрофрічні зміни у плаценті та у судинах плодово-плацентарної системи із зміною структури гемохоріального (плацентарного) бар'єра можуть бути однією з причин переношування вагітності та фракторами ризику негативного впливу на життєдіяльність плода.

ПРОЛОНГИРОВАННАЯ И ПЕРЕНОШЕННАЯ БЕРЕМЕННОСТЬ. КЛИНИКО-МОРФОЛОГИЧЕСКИЕ АСПЕКТЫ. НАМИ проведено динамическое наблюдение за 15 беременными с момента их госпитализации до выписки после родов. Беременные разделены на 3 группы: первая - 5 женщин с пролонгированной беременностью 41 неделя; вторая группа - 5 женщин с переношенной беременностью 42 недели; третья группа - 5 женщин с фризиологическим течением беременности. Критерии включения к исследованию: одноплодная беременность, срок гестации >280 дней, отсутствие в анамнезе тяжелой экстрагенитальной патологии, переношенная беременность в анамнезе. Все беременные обследованы в полном клинико-лабораторном объеме. В процессе обследования проводили общеклинические (клинико-анамнестические, лабораторные), специальные исследования: ультразвуковое обследование с допплерометрией, кардиотокографию, морфрологическое исследование плаценты и амниона. Показано, что у 60 \% женщин с пролонгированной беременностью в анамнезе - перенесенные детские инфекционные заболевания (краснуха, скарлатина, паротит). Средний возраст менархе у женщин с пролонгированной и переношенной беременностью составлял $15 \pm 0,5$ лет. У $40 \%$ беременных с переношенной беременностью диагностировали анемию легкой степени (Нв 98-100 г/л). Во время родов у $60 \%$ женщин с переношенной беременностью и у 40 \% с пролонгированной беременностью наблюдалось преждевременное излияние околоплодных вод. Морфологические исследования показали, что дистрофические изменения в плаценте и сосудах плодово-плацентарной системы, что ведут к изменениям морфологии гемохориального барьера, могут быть одной из причин перенашивания беременности и факторами риска отрицательного влияния на жизнедеятельность плода.

PROLONGED AND POST-TERM PREGNANCY. CLINICAL AND MORPHOLOGICAL ASPECTS. We conducted dynamic monitoring of 15 pregnant since their admission to hospital until the extract after labor. Women are divided into 3 groups: the first 5 - women with prolonged pregnancy -41 week; the second -5 women with post-term pregnancy -42 weeks; the third -5 women with physiological pregnancy. Criteria of inclusion into the investigation: singleton pregnancy, gestational age $>280$ days, the absence of severe extragenital pathology, post-term pregnancy history. All pregnant women were examined in full clinical laboratory capacity. During the research the following investigations were conducted: general clinical (clinical and medical history, laboratory), special: ultrasound with Doppler, cardiotocography, morphological studies of placenta and amniotic membranes. It is shown that in $60 \%$ of women with prolonged pregnancy in history childhood infectious diseases were observed (measles, scarlet fever, mumps). The average age of menarche in women with prolonged pregnancy and post-term was $15 \pm 0.5$ years. In $40 \%$ of pregnant women with post-term pregnancy mild anemia was revealed (Hb-98-100 g/l). During childbirth in $60 \%$ of women with post-term and in $40 \%$ with prolonged pregnancy premature discharge of amniotic fluid was observed. Morphological studies have shown that dystrophic changes in the placenta and in vessels of fetal-placental system with structural changes of hemochorial (placental barrier) may be one of the reasons of pregnancy prolongation and risk factors of negative impact on the vital functions of the fetus.

Ключові слова: пролонгована і переношена вагітність, плацента, амніон.

Ключевые слова: пролонгированная и переношенная беременность, плацента, амнион.

Key words: prolonged and post-term pregnancy, placenta, amnion.

встУп. Переношування вагітності є актуальною проблемою, над вирішенням якої на сьогодні працюють провідні науковці в даній галузі та практичні лікарі не тільки в Україні, а й за її межами. Актуальність даної проблеми визначається великим числом ускладнень у родах, високим відсотком оперативного розродження, високою перинатальною смертністю [1-4, 6]. Відсоток переношеної вагітності у країнах Європи і США 
коливається від 0,5 до 10 \%. Залежно від країни ризик перинатальної смертності - 0,7-5,8 \% у Європі і США [4]. У країнах Європи, зокрема у Франції, пролонгована вагітність ( $\geq 41^{+0}$ тиждень) діагностується у 15-20\% жінок і переношена вагітність $\left(\geq 42^{+0}\right.$ тижні) - приблизно 1 \% [4]. Етіологія і патогенез переношування вагітності на сьогоднішній день вивчені недостатньо, незважаючи на значний арсенал наукових публікацій, присвячених даній проблемі. За даними [2, 3], переношену вагітність не можна розглядати як один із варіантів нормальної вагітності, скоріше таку вагітність слід розглядати як патологічну проблему, що залежить як від стану матері, так і від стану плода. Перенесені раніше дитячі інсрекційні хвороби (скарлатина, паротит, краснуха та інші), які відіграють важливу роль у фрормуванні репродуктивної системи жінки, а також екстрагенітальні захворювання можуть бути преморбідним фоном для переношування вагітності [10]. На основі даних наукової літератури вияснено ряд причин переношування вагітності, серед яких зміна гормонального стану (високий рівень прогестинів та низький естрогенів), зміни у біометрії, диссрункції гіпофрізарно-адреналової системи плода, зміни у центральній нервовій системі матері $[7,8,11]$. Слід відзначити, що переношена вагітність частіше спостерігається у першороділь після 35 років і може повторюватись при наступних вагітностях [5]. Існують також дані про те, що у переношуванні вагітності важливу роль відіграють плацентарний лактоген та катехоламіни, рівень яких знижується при переношеній вагітності на $25 \%$ [5]. Окрім перелічених фракторів впливу показано також роль метаболічних процесів, таких, як ацидоз, десріцит вітамінів С, В, Р, Е, а також зниження мікроелементів, таких, як мідь, цинк, марганець у крові, міометрії та плаценті. Значну роль при переношуванні відіграє індекс маси тіла [9]. Численними науковими працями встановлено, що переношуванню вагітності сприяють перенесені аборти, інфантилізм, запальні захворювання внутрішніх статевих органів, порушення менструальної функції [2, 3, 5]. Переношування вагітності значно збільшує частоту ускладнень як для матері, так і для плода та новонародженого [6]. Згідно 3 [4], мертвонароджуваність при переношуванні збільшується до 5,8 \%, причому смертність плода може наступати як до початку пологової діяльності, так і під час пологів та у ранньому неонатальному періоді. Смертність плода при переношеній вагітності може бути обумовлена багатьма причинами, у тому числі зменшенням об'єму амніотичної рідини, при такій ситуації пуповина може стискатися між стінкою матки та плодом, особливо коли має місце обвиття пуповини навколо шиї або тулуба $[1,2,5,12]$. Новонароджені мають ознаки перезрілості - зменшення підшкірного жирового шару, зморщування шкіри на долонях та стопах, підвищення щільності кісток черепа та звуження швів та тім'ячок, збільшення довжини нігтів, відсутність першорідного мастила, зниження тургору шкіри, зміна маси тіла плода як у сторону його збільшення (>4500), так і в сторону його зменшення при затримці росту плода на $20 \%$ [5]. Основною причиною затримки росту плода вважають інфікування $[5,6]$. Одним із небезпечних ускладнень переношеної вагітності може бути аспірація плода меконіальними навколоплодовими водами, так званий меконій-аспіраційний синдром $[1,4]$ як під час вагітності, так і під час пологів. При переношеній вагітності також спостерігається дисфункція плаценти зі зміною трансплацентарного та плацентарно-плодового кровоплину, що погіршує постачання плода поживними речовинами та киснем [13]. Враховуючи актуальність проблеми та недостатність уваги до можливих морфологічних змін фретоплацентарного комплексу, нами запропоноване дане дослідження. Мета - дослідити особливості перебігу пролонгованої та переношеної вагітності та морфологічні характеристики плаценти, амніона та пуповини у даної категорії вагітних.

МАТЕРІАЛИ ТА МЕТОДИ. Проведено динамічне спостереження за 15 вагітними з моменту їх госпіталізації до виписки після пологів. Жінки розподілені на 3 групи: перша -5 жінок із пролонгованою вагітністю $\left(\geq 41^{+0}\right.$ тиждень); друга група - 5 жінок із переношеною вагітністю $\left(\geq 42^{+0}\right.$ тижні); третя група - 5 жінок із фрізіологічним перебігом вагітності. Критерії включення до дослідження: одноплідна вагітність, гестаційний вік >280 днів, відсутність тяжкої екстрагенітальної патології, переношеної вагітності в анамнезі. Усі вагітні були обстежені в повному клініколабораторному обсязі. У процесі обстеження проводили загальноклінічні (клініко-анамнестичні, лабораторні), спеціальні (ультразвукове дослідження з доплерометрією, кардіотокографрія, морфологічні дослідження плаценти та амніона) дослідження. Усі жінки ознайомлені з метою та методами, від них отримано письмову згоду на включення їх до наукового дослідження. Клінічні дослідження показали, що у 60 \% жінок із пролонгованою вагітністю в анамнезі спостерігалися перенесені в дитинстві інфекційні захворювання (краснуха, скарлатина, паротит та ін.). Середній вік менархе у жінок із пролонгованою й переношеною вагітністю становив $15 \pm 0,5$ років. У $40 \%$ вагітних із переношеною вагітністю виявлено анемію легкого ступеня (Нв 98-100 г/л). Під час пологів у $60 \%$ жінок із переношеною та у $40 \%$ із пролонгованою вагітністю спостерігалось передчасне вилиття навколоплодових вод. Після пологів забирали амніон, пуповину та плаценту. Проводили макроскопічне та мікроскопічне дослідження. Після макроскопічного обстеження плаценти та амніона вирізали кусочки плаценти з біляпуповинної ділянки, середньої частини плаценти та крайової ділянки. Гістологічний матеріал фріксували у 4 \% нейтральному формаліні. Зневоднення, ущільнення та заливку у парапласт здійснювали за загальноприйнятою методикою. Гістологічні зрізи завтовшки 5-7 мкм забарвлювали гематоксиліном та еозином.

РЕЗУЛЬТАТИ ДОСЛІДЖЕННЯ ТА ЇХ ОБГОВОРЕНня. При фрізіологічному перебігу вагітності макро- і мікроскопічні особливості плаценти відповідали терміну гестації. При макроскопічному обстеженні плаценти жінок із переношеною вагітністю в усіх 5 випадках на материнській поверхні плаценти спостерігалися невеликих розмірів інфраркти та окремі ділянки петрисрікації. Подібна ситуація виявлялася в жінок із пролонгованою вагітністю. Мікроскопічно у плаценті жінок з пролонгованою вагітністю спостерігалися ознаки старіння плаценти; дистрофрічні зміни синцитіотрофобласта, депозити фрібриноїду на поверхні ворсин та у міжворсинчастому просторі (рис. 1 А, Б). Діагностувався фріброз строми стовбурових ворсин, більш виражений на периферії плаценти. Стінки судин у таких ворсинках потовщені. Поряд із означеним 


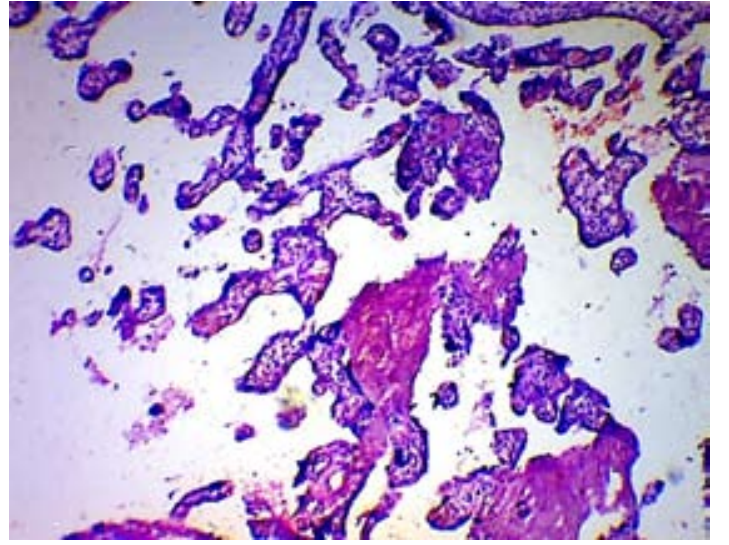

A

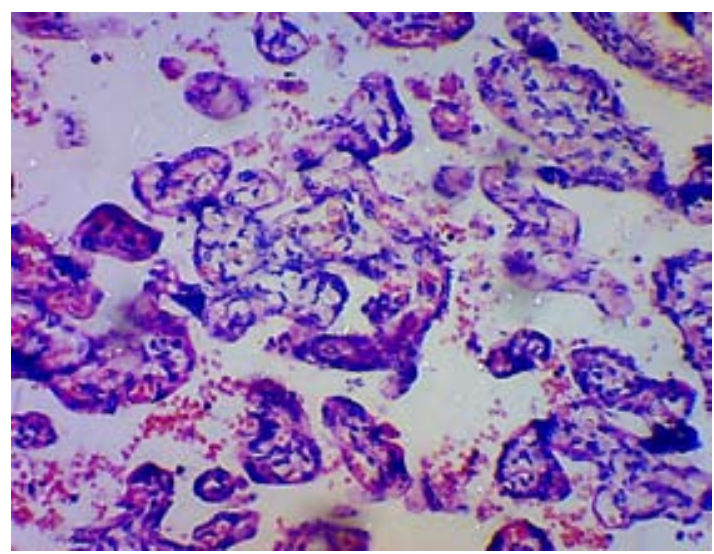

B

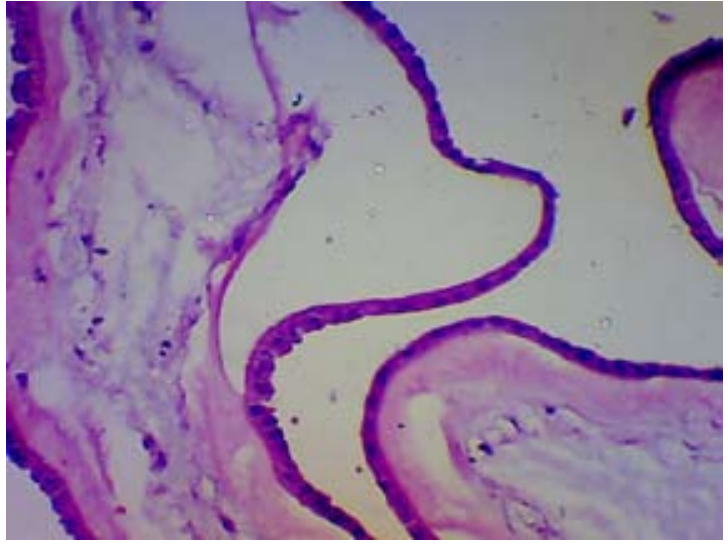

Б

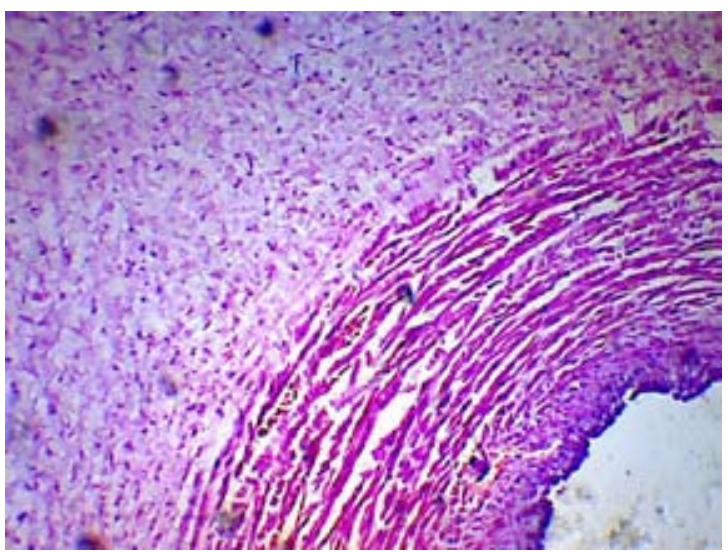

Г

Рис. 1. Морфологія фретоплацентарної системи. 41 тиждень вагітності. Гематоксилін-еозин, зб. х300.

А - ділянка плаценти 3 великою кількістю термінальних ворсин та значними депозитами фрібриноїду; Б - фррагмент амніона з десквамованим епітелієм; В - ділянка плаценти з набряком строми термінальних ворсин; Г - набряк стінки пуповинної артерії та просякання її еритроцитами.

при пролонгованій вагітності у перифрерійних ділянках трофробласта спостерігалися скупчення елементів синцитіотрофобласта (синцитіальні вузлики) на поверхні термінальних ворсин, що свідчить про процеси пролісрерації хоріального епітелію. Подібні зміни при пролонгованій вагітності спостерігали [2]. У плаценті жінок 3 переношеною вагітністю (рис. 2 А, Б, В) склеротичні зміни виражені більш інтенсивно, варто відмітити, що такий фракт мав місце не тільки у стовбурових ворсинках, а і в термінальних ворсинках, які були збіднені на кровоносні судини. В окремих ділянках плаценти констатували термінальні ворсинки з гіперплазією та кровонаповненням гемокапілярів. Спостерігалися також ворсинки з розпушеною стромою, які були подібні до таких на ранніх етапах вагітності (рис. 2 В). Поряд з ознаками старіння зустрічаються ознаки незрілості плаценти. Подібну ситуацію відмітили [13]. Одночасно констатували відсутність цитотрофобласта та набряк строми в окремих ділянках, що свідчить про виражені дистрофрічні зміни. Подібні зміни у плаценті спостерігаються не тільки при переношеній вагітності, а і при прееклампсії $[2,13]$. Однак, на відміну від пізніх гестозів, при старінні плаценти не виражені ознаки компенсаторно-адаптивного характеру на тканинному рівні. Дистрофрічні зміни у плаценті можуть бути одним із фракторів, що сприяє переношуванню вагітності.
Проте не можна виключати, що такі зміни розвиваються як вторинні внаслідок продовження терміну вагітності. В амніотичній оболонці жінок із пролонгованою вагітністю спостерігалися ділянки відшарування амніотичного епітелію (рис. 1 Б), незначний набряк компактного шару, складки амніотичної оболонки в окремих випадках досить глибокі. Складки амніона, правдоподібно, пов'язані з передчасним вилиттям навколоплодової рідини. У жінок з переношеною вагітністю більш виражені означені зміни, як мукоїдне набухання компактного шару амніона, у губчастому шарі скупчення клітин цитотрофобласта 3 вакуолізованою цитоплазмою (рис. 2 Г, Е). У біляпуповинній ділянці та у пуповині видно мукоїдне набухання вартонових драглів, набряк зовнішньої оболонки судин, розшарування стінки судин (рис. 2 Д) та просочування їх орорменими елементами крові. В окремих випадках присутні еритроцитарні сладжі у просвітах артерій пуповини. Відшарування амніотичного епітелію свідчить про дистрофічні процеси амніона, зменшення продукції та резорбції амніотичної рідини, а мукоїдне набухання вартонових драглів, розшарування стінки артерій пуповини та набряк зовнішньої оболонки судин - ознака порушення процесів плодово-плацентарного кровопостачання і як фрактор ризику негативного впливу на життєдіяльність плода. 


\section{Акушерство та гінекологія}



A

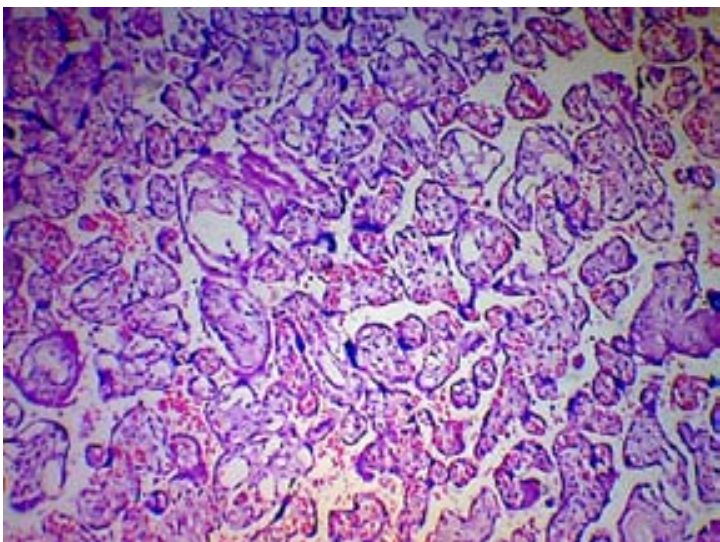

B

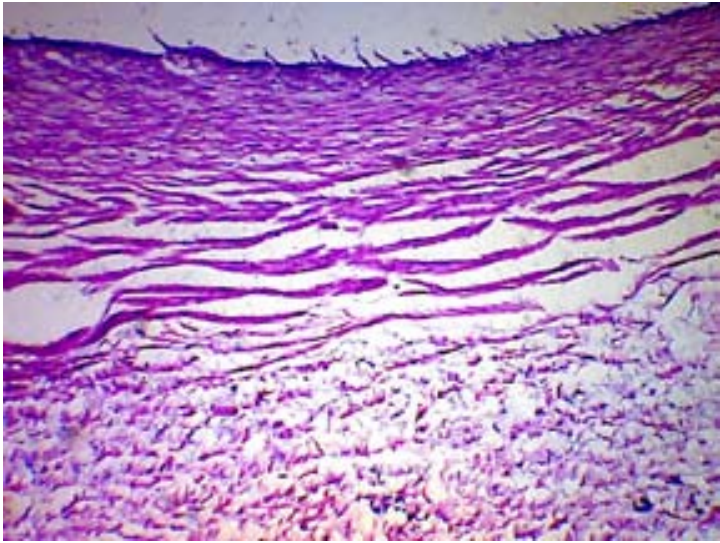

Д

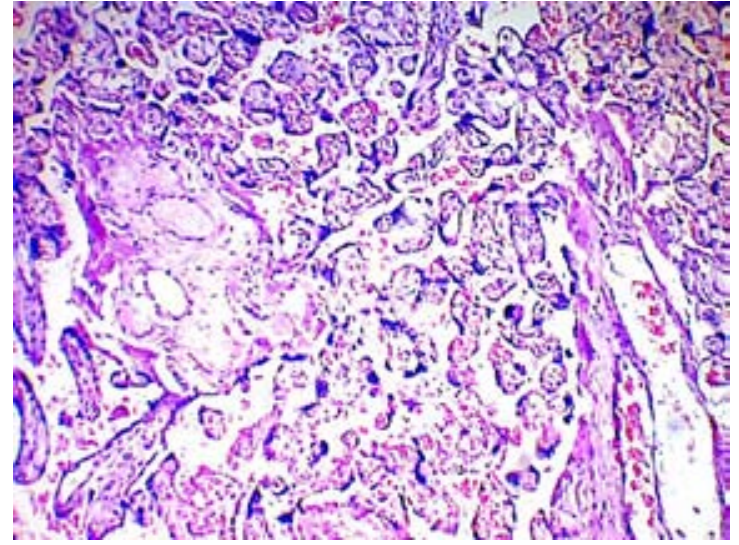

5

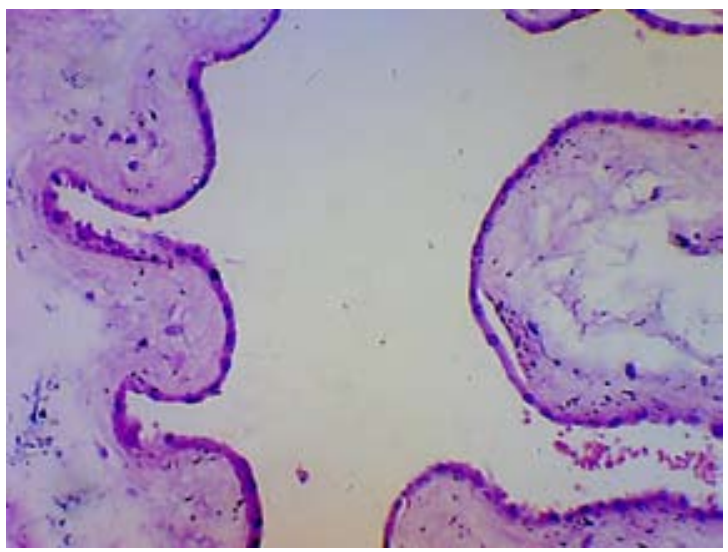

$\Gamma$

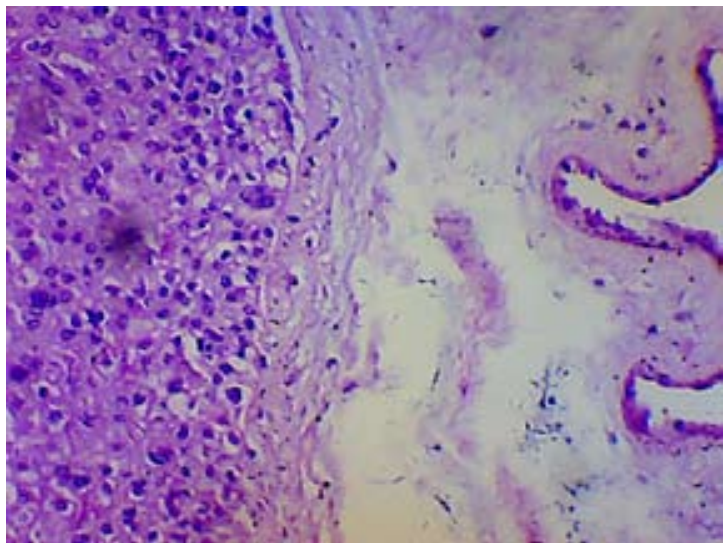

$\mathrm{E}$

Рис. 2. Морфологія фретоплацентарного комплексу. 42 тижні вагітності. Гематоксилін-еозин.

А - велика кількість дрібних склерозованих ворсинок та стовбурова ворсинка 3 магістральною судиною, заповненою еритроцитарним сладжем, зб. х120; Б - територія ущільнення термінальних ворсинок, запустіння судин стовбурових ворсинок, зб. х120; В - ворсинки з вакуолізованою стромою, зб. х120; Г - еритроцити у просвіті амніона, ділянки десквамації епітелію, набряк компактного шару амніона, зб. х300; Д - розшарування стінки артерії пуповини, зб. х300; E - некротичні зміни у компактному шарі амніона, вакуолізовані клітини цитотрофобласта в губчастому шарі, зб. х300.

ВИСновоК. Морфоорункціональні зміни у плаценті жінок із переношеною вагітністю зі зміною структури гемоплацентарного бар'єра можуть бути однією 3 причин переношування вагітності. Дистрофрічні процеси амніона, зменшення продукції та резорбції амніотичної рідини, набряк компактного шару амніона та вартонових драглів пуповини, розшарування стінки артерій пуповини
- ознака порушення процесів плодово-плацентарного кровопостачання і як фрактор ризику негативного впливу на життєдіяльність плода.

ПЕРСПЕКТИВИ ПОДАЛЬШИХ ДОСЛІДЖЕНЬ. У перспективі планується детальне вивчення фетоплацентарного комплексу з використанням сучасних методів імуногістохімії при пролонгованій та переношеній вагітності . 


\section{СПИСОК ЛІТЕРАТУРИ}

1. Маркін Л. Б. Диференційований підхід до ведення вагітності після 41-го тижня / Л. Б. Маркін, С. Р. Смуток // Медицинские аспекты здоровья женщины. - 2011. - № 2. - С. 5-9.

2. Чернуха Е. А. Переношенная и пролонгированная беременность / Е. А. Чернуха. - М. : ГЭОТАР-Медиа, 2007. - 207 с.

3. Яремко Г. Є. Сучасні аспекти проблеми переношування та пролонгування вагітності / Г. Є. Яремко, І. А. Жабченко, Т. М. Коваленко // Жіночий лікар. - 2013. - № 3. - С. 5-9.

4. Prolonged and post-term pregnancies: guidelines for clinical practice from the French College of Gynecologists and Obstetricians (CNGOF) / C. Vayssiere, J. B. Haumonte, A. Chantry [et al.] // Eur. J. Obstet. Gynecol. Rep. Rod. Biol. 2013. - Vol. 169, № 1. - P. 6-10.

5. Діденко Л. В. Переношена вагітність. Сучасний погляд на ведення вагітності і розродження / Л. В. Діденко // Жіночий лікар. - 2010. - № 1 (27). - С. 39-41.

6. Postterm pregnancy. M. Galla, I. Symond, H. Murray [et al.] // Facts ViewsVis Obgyn. -2012. - Vol. 4 (3). - P. 175-187.

7. Patterns of plasma corticotropin-releasing hormone, progesterone, estradiol, and estriol change and the onset of human labor / R. Smith, J. I. Smith, X. Shen [et al.] // J. Clin. Endocrinol. Metab. - 2009. - Vol. 94. - P. 2066-2074.
8. Corticotropin-releasing hormone inhibits progesterone production in cultured human placental trophoblasts / R. Yang, X. You, X. Tang [et al.] // J. Mol. Endocrinol. - 2006. - Vol. 37 (3). - P. 533-540.

9. Outcome of pregnancy in a woman with an increased body mass index / T. S. Usha Kiran, S. Hemmadi, J. Bethel [et al.] // BJOG. - 2005. - Vol. 112. - P. 768-772.

10. Who is at risk for prolonged and postterm pregnancy / A. B. Caughey, N. E. Stotland, A. E. Washington [et al.] // Am. J. Obstet. Gynecol. - 2009. - Vol. 200 (6). - P. 683e1-683e5.

11. Maternal plasma corticotrophin-releasing factor and urocortin levels in postterm pregnancies / M. Torricelli, E. Ignacchiti, A. Giovannelli [et al.] // Eur. J. Endocrinol. - 2006. - Vol. 154 - P. 281-285.

12. Salomon L. J. How to date pregnance?/ L. J. Salomon // De Gynecolodie Obstetrigue et Biologie de la Reproduction. 2011. - Vol. 40. - P. 726-733.

13. Милованов А. П. Кореляционные связи морфологических и фрункциональных показателей плаценты и новорожденного при нормальной доношенной, пролонгированной и истинно переношенной беременности / А. П. Милованов, М. В. Федорова // Архив патологии. - 2011. - № 3. - С. 50-53. 